\title{
Toros y toreros
}

Keywords: derecho; legislación; jurisprudencia; animal

El título de mi editorial, coincide con el de un libro que he buscado durante años [1] , que he tenido la oportunidad de tener entre las manos una vez, en una librería de München (y entonces no lo pude comprar...), y cuyas imágenes y textos aún tengo clavadas en la memoria. Un libro bellísimo y editado con una calidad excelsa. Ese tipo de obras que a los amantes del arte y de la lectura, a los amantes de los libros, nos gusta tanto ver y tocar, como abrir sus páginas y leer o mirar las imágenes. Una preciosidad. El libro reproduce la serie de Picasso dedicada a la tauromaquia, con textos de Luis Miguel Dominguín, con quien, es sabido, mantuvo el pintor una estrecha relación de amistad y colaboración; Picasso fue el padrino de uno de los hijos del torero. Uno de esos episodios que, de tanto en tanto, se asoman a la prensa llamada rosa, de forma insospechada.

El mundo del toro tiene un singular atractivo, color, música, plasticidad, riesgo abierto, pases que suspenden el aliento. Eso que se llama arte, en alguna medida. No puedo negar que en algún momento de mi vida, hace años, experimenté esa fascinación por un espectáculo absolutamente singular. Sin embargo, me bastó un instante, percibir el inmenso dolor del toro en cualquiera de las suertes, para pasar a mirar al toro y no al torero. Lo que el espectador hace en la plaza es mirar y aplaudir el arrojo, el coraje, la finura del torero, pero no mira al toro. Y si lo mira, no lo vé. No vé que se desangra y que muje de dolor, no vé que se arrastra y que se cae cuando la puya del picador ha hendido sus terminaciones nerviosas, no vé que le clavan agudas banderillas en una zona ya castigada y ensangrentada, no vé que aún está vivo cuando lo apuntillan... Todo eso también me ocurrió a mí, yo no lo veía. Miraba y veía al torero, sólo miraba el espectáculo -inconsciente de lo que estaba sucediendo en realidad-; al toro, no le veía. Era como un comparsa necesario, como un elemento más de una tarde de fiesta. Pero no lo veía como un animal, que siente dolor y que lo manifiesta.

En el debate que ha abierto la prohibición de las corridas de toros en Cataluña el pasado 28 de julio, se han vertido todo tipo de comentarios. El reflejo que la noticia ha tenido en la prensa internacional, ha sido innegable [2] . En España, no podía ser de otra forma, la reacción ha sido apasionada y aún no ha cesado. Por ello, quiero terciar aquí en beneficio de lo que considero relevante y que puede resumirse en unos pocos postulados:

-La iniciativa (ILP) que ha logrado la prohibición de las corridas de toros en Cataluña, ha sido realmente popular. Las firmas se recogieron a pie de calle por voluntarios de todo tipo, desde jóvenes y miembros de ONGs, hasta tenderos ("botiguers") que cedían un recodo de su mostrador para colocar el pliego de firmas. Se recogieron 180.000. No es poco. Detrás de ello ha estado el trabajo y la ilusión, el desinterés de muchos ciudadanos anónimos.

-La tramitación de la ILP, tenía necesariamente que pasar el debate parlamentario y quien, en último término, iba a decidir la modificación o no del Art. 6 del texto refundido de la Ley de Protección de los animales [3] -que de eso técnicamente se trataba-, fueron los representantes de los pártidos políticos presentes en la Cámara. Que de tal iniciativa popular se hayan extraído consecuencias políticas, era previsible, pero ello no obsta para que la finalidad de la misma, la protección del animal, haya quedado por ello alterada [4].

-Si se pone el acento en la intervención política y en la llamada batalla identitaria, a propósito de las corridas de toros, otro tanto habría de hacerse con cualquier propuesta de ley, de carácter innovador o 
reformador de lo que se ha venido legislando en los últimos tiempos. No pondré ejemplos recientes, por resultar obvios para cualquier jurista. No hay duda de que el derecho es un producto histórico y, naturalmente, siendo una ciencia jurídicosocial, se impregna de lo que suele calificarse de binomio inescindible Derecho-Sociedad.

-La tradición o la identificación de una determinada celebración con las constantes nacionales, no puede convertirse en salvaguarda para perpetuar prácticas, convertidas por el uso en "tradiciones", en las que se tolere el maltrato de un animal [5]. El toreo no se concibe sin el sacrificio cruento de un animal vivo, por dicha razón no es admisible, aunque sea, parezca o se manifieste con aspectos hermosos. A este propósito de la tradición, quisiera recordar la advertencia hecha por el Tribunal Superior de Justicia de Valencia [6] , en relación con la prohibición de la suelta de patos en el puerto de Sagunto, que venía celebrándose, a pesar de algunas multas, en el sentido de que "ninguna tradición puede ser la excusa para dar un tratamiento antinatural a los patos”. Empieza a dibujarse una línea jurisprudencia, cada vez más clara, a favor del respeto por los animales. Aún estamos lejos de defender sus “intereses”, como se hace en otros países, como algo que ha calado en el Derecho y en la conciencia ciudadana, pero hay movimientos en la historia -y éste es uno de ellos- que difícilmente tienen vuelta atrás.

-La historia puede hacerse servir para defender determinados intereses. Pero la historia es tozuda y como consiste en el estudio de verba (es decir, textos, palabras, reflexiones escritas) y no de facta (hechos, sucedidos, batallas...), se resiste a hacer mentir a los textos, a los documentos. En algún momento, a veces transcurren siglos, aparece el documento con el que puede contrastarse o rebatirse una afirmación. En tema de toros, las prohibiciones se han sucedido en España desde el S.XVI en adelante, ahí están los documentos que lo prueban. En el S. XVIII, se debe a Jovellanos la iniciativa de desarraigar de España una tradición violenta y feroz; en todo el S.XVIII, los intelectuales europeizados aborrecían un espectáculo de muerte y sangre, impropio de ciudadanos. El número de festejos de ese tipo, era significativamente pequeño y no estaba extendido por toda la geografía nacional.

-La prohibición en Cataluña de las corridas, se apoya también en la carencia de una tradición arraigada. Sólo hay que recordar que la Monumental de Barcelona sólo se inauguró en 1914 y, como bien recuerda Henry Kamen [7], siendo alcalde de Barcelona el Dr. Robert, promovió en 1901 una asamblea popular para pedir la abolición de las corridas. Por lo demás, la legislación sobre protección animal es en Cataluña de las más antiguas en el ámbito autonómico: en 1988 se promulga la primera "Ley de Protección Animal”, que ha sido reformada recientemente [8]. Junto con los Códigos de Austria, Alemania y Suiza, el Código civil de Cataluña, declara, en el capítulo dedicado a las cosas en propiedad, que "los animales no son cosas” y se rigen por normas específicas [9]. Con ello se apartan estos Códigos de la tradición romana, seguida por el resto de Códigos Europeos y Latinoamericanos, en los que a los animales se les considera “cosas” en propiedad.

Las bases para un cambio, guste o no, estaban en Cataluña echadas [10]. Y ello, independientemente de que la política haya sacado réditos de lo que la sociedad demandaba.

[1] P.Picasso \& Luis Miguel Dominguin, Toros y Toreros (Éditions Cercle d’Art 1961).

[2] Recopilación de noticias por Oriol Caudevilla Descargar

[3] Texto refundido de la Ley de Protección de los animales, aprobado por decreto legislativo 2/2008 de 15 de abril Descargar

[4] Comparecencia del Prof. Javier de Lucas ante la Comissió de Medi Ambient i Habitatge del Parlament de Catalunya (4.3.2010) Descargar

[5] Comparecencia del Prof. Pablo de Lora ante la Comissió de Medi Ambient i Habitatge del Parlament de Catalunya (4.3.2010) Descargar

[6] Publicada en Las Provincias, Link externo

[7] H.KAMEN, Consideraciones sobre la fiesta nacional, en EL MUNDO (11.8.2010), sección Tribuna 17.

[8] Link interno

[9] Libro 5 del Código civil de Cataluña, Llei 5/2006, de 10 de maig, del llibre cinquè del Codi civil de Catalunya, relatiu als drets reals, art. 511-1-3 Bienes: 3. "Los animales, que no se consideran cosas, están bajo la protección especial de las leyes. Solo se les aplican las reglas de los bienes en lo que permite su naturaleza"

[10] Mercedes Cano-Herrera Tauromaquia e identidad moral de Cataluña , en dA web Center, Junio 2010 